\title{
Challenges to Food Security in India
}

\author{
Dr. Sultan Singh Jaswal \\ Associate Professor Department of Commerce Govt. College Dhaliara Kangra (H.P.) Pin;- 177103
}

\begin{abstract}
Food security is access to enough food by all people at all time for an active and healthy life. India is truly developing now and its income, infrastructure, per capita income has also developed .But the major problem faced by India is "the problem food management and it's distribution". Agriculture is very important to India, employing 55\% of its population and providing $16.5 \%$ of its annual GDP. Today, India ranks second worldwide in farm output..India is the largest producer in the world of milk, cashew nuts, coconuts, tea, ginger, turmeric and black pepper. It also has the world's largest cattle population (281 million). It is the second largest producer of wheat, rice, sugar, groundnut and inland fish. It is the third largest producer of tobacco. India accounts for $10 \%$ of the world fruit production with first rank in the production of banana. Despite ensuring ample availability of food, existence of food insecurity at the micro-level in the country has remained a formidable challenge for India. In the recently released Global Hunger Index of 2013, India ranked 63rd out of 120 countries and this report is quite disturbing because India is one of the largest producers of food in the world. Still India is not in the condition to meet the basic food requirements of people. There are many people in India who strive hard even for the square meals. I don't say that people in village areas are facing this problem, but also people in major cities face the same problems!!Lack of food supply and the nutritional deficiency causes not only a bad mark for the country's image in the international level, but also causes adverse effect on country's developing economic policies and it's structure. Mismanagement of food products and it's supply also puts country under many dreadful diseases too! This paper is focused on the several foods security issues prevalent in the Indian scenario. Data are taken from relevant sources to analysis the gravity of the food security issues in India. It also covered the several development programmes taken up by the Indian government to counter various food security issues including several schemes and yojanas. India's biggest challenge still remains ensuring food and nutritional security to its masses.
\end{abstract}

Keywords: Food security, Challenges, GDP, Mismanagement of food products, Global Hunger Index (GHI).

\section{Introduction}

Eat food is essential for living like air and water. It is more than getting two square meals. It hasthree dimensions- 1) food availability i.e. total food production in the country plus the imported food plus uffer stocks maintained in govt. granaries like FCI in previous years. 2) food accessibility i.e. food should be within the reach of every person. 3) food affordability i.e. an individual should have enough money to buy proper, safe and nutritious food to meet his dietary needs.

The need for achieving food security is felt significantly in the recent years due to enormous pressure from the ever increasing population in India. India after 66th year of independence has not only seen development and progress but also becoming one of the fastest growing economies in the world. This accomplishment takes a shattering twist when one looks at the hunger problem booming within it. Out of the estimate 1.27 billion population, a total of $77 \%$ are considered poor and vulnerable, and millions of people fail to get two square meals a day. In the recently released Global Hunger Index of 2013, India ranked 63rd out of 120 countries and this report is quite disturbing because India is one of the largest producers of food in the world.

The existence of this problem is not merely confined to rural areas but also extend to urban region. To combat this perennial problem, Government did introduce some major programme such as Public food distribution system (PDS), the Integrated Child Development System (ICDS), Mahatma Gandhi National Rural Employment Guarantee Act (MGNREGS), Antyodaya Anna Yojana (AAY) etc. This major programme fails to penetrate in every section of the society and hunger continues to thrive among the poor people. The disappointment in the failure of this programme can mainly be attributed to the prevalence of inequality among the society, unsuccessful delivery of public services, pathetic liability system and infringement in the implementation of pro-poor policies. In this backdrop, the National Advisory Council (NAC) drafted a new "Food Security Bill" in 2010, the bill which is considered as the biggest ever experiment in the world for distributing highly subsidized food for any government through a "rights based" approach . The National Food Security Bill after much debate and analysis was passed and became a law on 12th September 2013. According to this Act, Food Security is defined as the availability of sufficient food grains to meet the domestic demand as 
well as access, at the individual level, to adequate means of food at affordable prices.. The globally recognized definition of food security is access to food at the household level at all times to ensure a healthy and active life for all its members. The household is accepted as the unit for consideration, rather than, let us say, a country or an administrative subunit of it because for food security to be meaningful, food must not only be available at these higher levels, but must be accessible at the lowest unit, the household, and indeed every single member within it too. In fact, a central aspect of food security is the discrepancy between availability (at a higher level) and accessibility (at the lowest level). The paradox or scandal noted above is a manifestation of that discrepancy.

Consider the situation in our country. Foodgrain production increased from around 50 million tonnes at the time of Independence to over 200 million tonnes in recent years. Although what was being produced at the time of Independence and for a couple of decades thereafter was not adequate to meet the caloric requirements of the people, we have now reached a situation where, if what is produced is distributed equally, the minimum requirements of all can be met in spite of the tremendous increase in population over more than half a century. In no part of the world is the foodgrains equally distributed, but the hypothetical calculation goes to show that availability is not the main issue. Calculations show that in the future also, say in 2030 or 2050, the situation is likely to be similar. Not that all matters relating to availability have been solved. But India, though still in the low ranks in terms of per capita availability of food, has reached the stage where, as far as food security is concerned, the accent can be, and has to be, on access of different sections of the population to what is available.

\section{Objectives of the paper}

(a) What is the progress in food supply in terms of availability at the national level?

(b) How far has India progressed in terms of access to food and nutrition requirements at the household level?

(c) What are the programmes and policies India has followed in order to realize food and nutrition security?

(d) What should be done to realize food and nutrition security for all the citizens of India?

\section{Methodology:}

The present study is based on the secondary data published by various agencies and organizations. The present study makes use of data and information provided by IFPRI, Global Hunger Index of 2013,FCI, Ministry of Agriculture, Newspapers, Magazines, Books, Economic journals and Internet etc.

\section{Why food security is needed in India?}

The International food policy research institute (IFPR) classified the status of hunger into five category-low, moderate, serious, alarming and extremely alarming. India falls into the category of alarming. The most important aspect contributing to this development is the non availability of basic requirement of food. It has been observed that the consumption of food, in terms of nutrition and quantity, is lacking far behind. According to the study conducted by National Institute of Nutrition, the minimum per capita food grain required for an adult is $182.5 \mathrm{~kg} /$ year whereas in India, the availability is only $173.6 \mathrm{~kg} / \mathrm{year}$ and as far as the protein requirement is concerned, the daily intake should be 50mg but the situation seems to remain stagnant, the per capita daily intake is only $10 \mathrm{mg}$

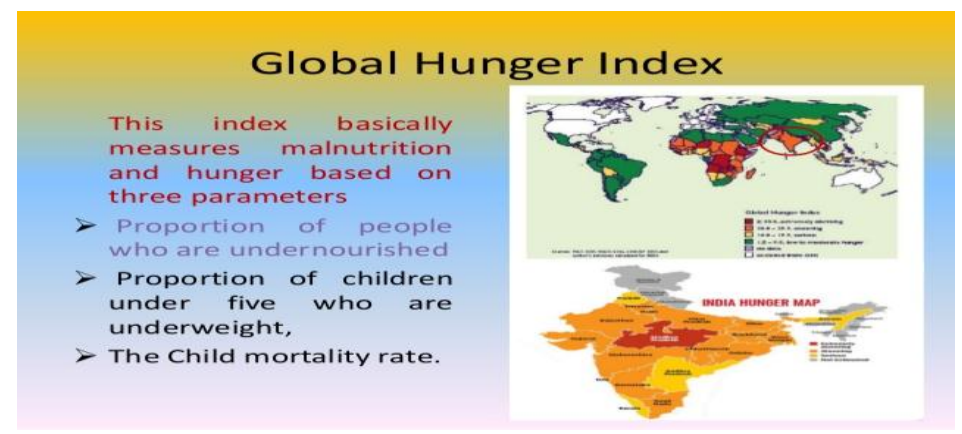


Global Hunger Index of 2013, India ranked 63rd out of 120 countries TABLE-1

\begin{tabular}{|l|l|l|l|l|}
\multicolumn{5}{|c|}{ Performance on Global Hunger Index } \\
\cline { 2 - 5 } & \multicolumn{5}{|c|}{$\begin{array}{l}\text { Rank in Hunger } \\
\text { index }\end{array}$} & $\begin{array}{l}\text { Out of total no. } \\
\text { of countries }\end{array}$ & & Score \\
\hline Year & & & & \\
\hline 1990 & & 118 & 31.73 & Alarming \\
\hline 2007 & 94 & 88 & 25.03. & Alarming \\
\hline 2008 & 66 & 88 & 23.70 & Alarming \\
\hline 2009 & 65 & 84 & 23.90 & Alarming \\
\hline 2010 & 67 & 81 & 24.10 & Alarming \\
\hline 2011 & 67 & 79 & 24.2 & Alarming \\
\hline 2012 & 65 & 120 & 22.9 & Alarming \\
\hline 2013 & 63 & 21.3 & Alarming \\
\hline
\end{tabular}

TABLE--1 shows that India has moved from $\mathbf{6 5}^{\text {th }}$ to $\mathbf{6 3}^{\text {rd }}$ in the Global Hunger Index of 2013, making a marginal improvement since 2012,but continues to suffering far behind other emerging countries. The score for India has improved slightly from 22.9 in 2012 to 21.3 in 2013.

Further studies have indicated that consumption and expenditure on food grain have decrease up to a certain level due to increase in food prices and enlargement in the consumption of non-food item. Malnutrition and poverty are the main causes for the adoption of food security in India. Every year nearly 5000 children die due to inadequate food consumption. HUNGAMA report published by Nandi Foundation in 2011 found that $42 \%$ of the children under the age of five are underweight and 59\% are stunted. Above this, a study conducted by Food and Agricultural Organisation found that 225 million people i.e. 23\% of our population are undernourished and 260 million people falls under the category of above the poverty line (APL). The increase in the number of APL household is supposed to decrease the number of undernourished people but it is happening the other way round.

\section{India's Food Security Challenges}

Food security is the back bone of national prosperity and well being. The health of any nation is directly linked to food security. Food security may be defined as availability of food and access to it. A family is considered to be food secure when it's members do not live in hunger or fear of starvation. As per definition of FAO- Food Security exists when all people, at all times, have physical and economic access to sufficient, safe and nutritious food to meet their dietary needs and food preferences for an active and healthy life. There is direct relationship between food consumption levels and poverty.In India, 30 million people have been added to the rank of hungry since the mid 1990s and 40\% children are underweight. World wide 852 million people are hungry due to extreme poverty and 2 billion people lack food security intermittently due to varying degree of poverty(Sources FAO, 2003). 600 million children die of hunger every year and17000 everyday.

In India approximately, 320 Indians go to bed without food every night and recent data is very much alarming and situation is going even worse. Food riots have taken in many countries of the world. It's becoming very difficult to maintain food security. In rural context, agriculture development for small and marginal farmer is the most important dimension of food security. The diversification of agriculture for food e.g., cereals, pulses, edible oil yielding, vegetable, fuel $\&$, timber yielding plants, medicinal and fodder crops are necessary to meet the food and augment income to farmers to meet the food security. Natural vagaries like excessive rainfall, drought, and availability of water for irrigation, undulating topography, soil erosion, and soil type such as degraded soil, acidic \&alkaline soil affect the food security. The income levels of farmer families govern the access to food affordability. Food distribution is a big problem. PDS (Public Distribution System) is not satisfactorily functioning. The families very poor within adequate income cannot escape food crisis. Globalization may and may not help food security. However, there are people who feels that globalization will definitely help food security due to trade but it's matter of debate. We will have to aim at food security in developing countries through increased and stabilized food production on an economically and environmentally sustainable technologies/ methods. Diversification in agriculture is highly required. We can not afford to huger, malnutrition and famine.

Accordingly, all of us including Govt. policies seriously need to redesign in order to meet the 
present demand and fill the gap of exiting system in order to ensure food security to every citizen of the country

\section{While making grain available to all is important, it is equally essential to ensure that all food supplied for consumption remains unadulterated and uncontaminated. Challenge of contamination}

- Still, food security, which seeks to end starvation, does not abolish food adulteration. Virtually all items of food in India have chemicals or adulterants added to them, which make them unsafe to various degrees. Therefore, every public institution where food is served must ensure that what is served is chemically safe, nutritionally healthy and makes for the health of the nation.

- This means an organised system of inspecting the quality of food offered in public places. We should be under no illusion that even godowns where grain is kept for easy distribution have enough safety features incorporated in them.

- The business of making food appear appealing and attractive often spoils the quality of what we eat. To make the nation healthy, every citizen must be able to buy food that is free from contamination. This will involve a comprehensive process involving testing facilities or laboratories even in the villages. We must have a food safety project that makes what we eat wholesome. Food security cannot be guaranteed merely by the provision of a certain quantity of grain to each family but by ensuring that every grain that is distributed is wholesome and nourishing, and not noxious. The ideology of food safety is a composite one, beyond merely making grain available physically.

- $\quad$ Needed measures

- We must have a state-sponsored food safety foundation that has branches all across each State, with equipment that can test food safety. An empowered force of trained food safety personnel should visit eateries, food stores, even festival venues where food is served, and take action where adulteration or contamination is detected through scientific means. The food safety police must have suitable powers conferred on them under legislative sanction. There should be an Act that provides statutory instrumentality to thus ensure the health of the people. A safety police force operating under the Health Ministry with powers of seizure is a new concept that will require an amendment to the Food Safety Act. Policing the process is a fundamental obligation of the state.

- The destiny of India is as yet uncertain. Jawaharlal Nehru said in a celebrated speech: "The service of India means the service of the millions who suffer. It means the ending of poverty and ignorance and disease and inequality of opportunity. The ambition of the greatest man of our generation has been to wipe every tear from every eye. That may be beyond us but as long as there are tears and suffering, so long our work will not be over."

- The Food Safety Bill has a serious shortcoming, and this must be corrected by means of suitable amendments and policy reformation. The prices of vegetables and other necessary commodities for food consumption keep rising and it is still not clear what the government is doing to control the trend.

- To end starvation, the prices of all food commodities must be regulated. Real food safety is the havenot humanity's instrument of contentment.

\section{Farmers issue}

The prevailing situation in the contemporary farming community needs serious attention in order to produce 61.2 million tonnes of food grain. Food and non- food prices have increased significantly in recent years and it's becoming unaffordable for the poor families to cope with the rising price. The expenditure on cultivation has increased extensively but the agricultural income has not increased in proportion with its input. In recent years, real wages in agriculture has increased much faster than the real growth in gross value added in agriculture. During the period (2007-2011), real farm wages recorded an average growth rate of $6.8 \%$ while real growth in agriculture was only $3.3 \%$.

This has put serious distress among the farmers. Another equally significant factor is the energy. Energy plays an important role in determining the output of production. The increase in the price of the energy has affected the food prices in two ways. Firstly, the rise in the price of petroleum product motivates the government and the corporate sector to go for producing bio-fuel. The policy for production of bio diesel from Jatropha plant and ethanol from molasses has already been initiated. This will seriously reduced the land area under cultivation for the production of food grain.

Secondly, the raising price in the inputs likes fertilizers, pesticides and cost of mechanical cultivation has made agricultural production very expensive. The share of mechanical and electrical power in the total power consumption has increase significantly from $39.63 \%$ in $1972-1973$ to $86 \%$ in $2005-2006$, while corresponding human and animal power has come down from $60.37 \%$ to $13.4 \%$ during thesame period. 
In recent years, with the increase of income and changes in the dietary pattern, the middle class families have been spending more on horticulture and livestock product as it provides more nutrients. And on the other hand the poor farmers whose income remains more or less stagnant see this as means to earn more income. Marginal farmers change to more income oriented occupation to support their household. Considering this, there is a possibility that the production of horticulture or livestock production may increase tremendously but the whole purpose of food security will be useless as this product are costly and poor people will not be able to afford it. This current development will have serious effect on the sustainability of food security. Not only it will reduce the area under cultivation but it will also increase the demand for feed grain and subsequently increasing the cereal prices, affecting the poor household.

Another critical issue which need to be focused for food security is the diversion of cultivated land towards wood farming. High GDP growth is leading to the increase consumption of wood and wood products like furniture, timber, pulp and paper. The cultivation of poplar tree in some states of northern India has turned out to be more remunerative than crop cultivation. And many farmers are leaning towards as it is more profitable.

\section{Safe Storage Of Food Grains And Inadequate Storage Facilities}
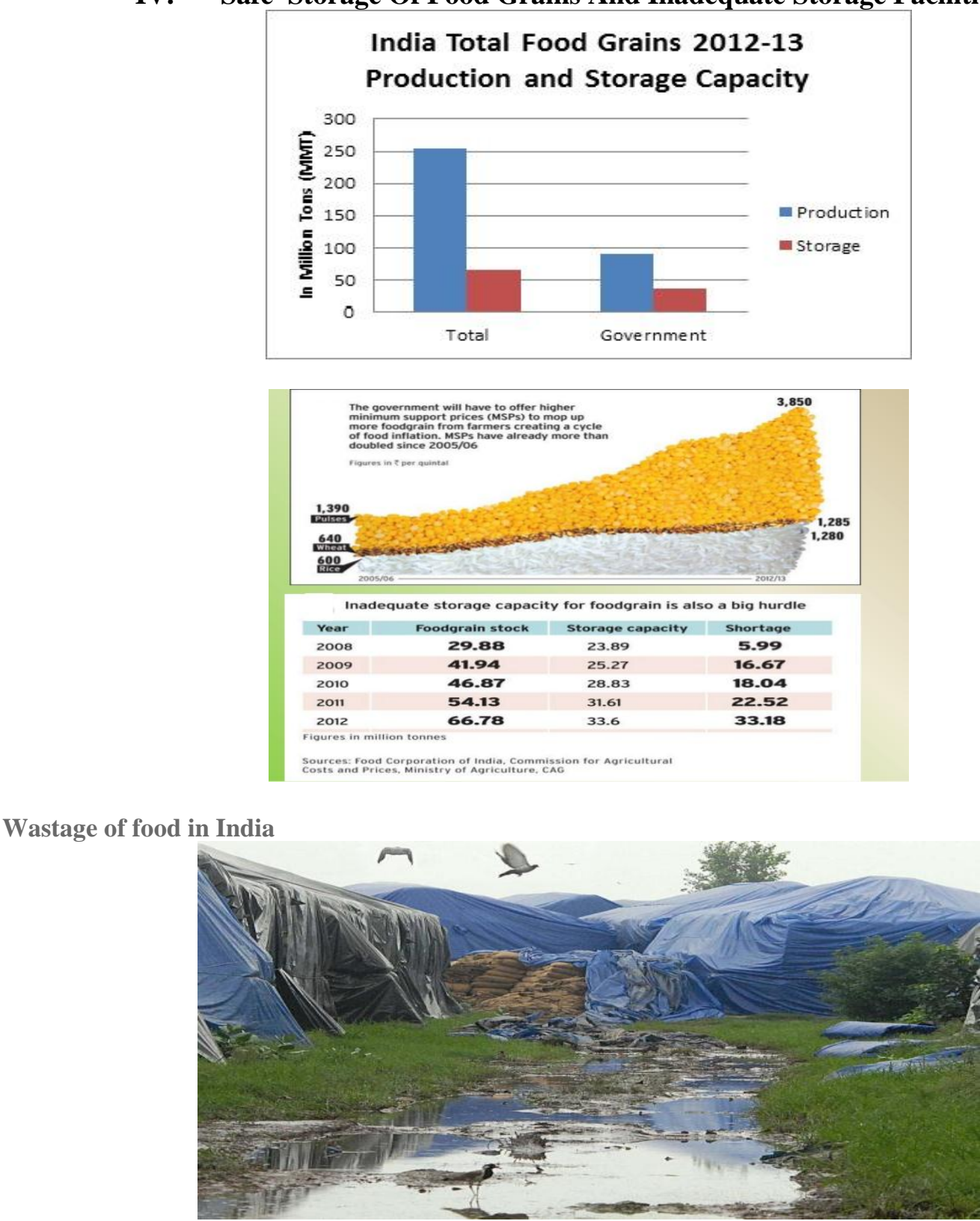

Picture-1 
A file picture shows birds feast on wheat spilling out of damaged sacks at an open storage facility of the Food Corporation of India on the outskirts of Karnal in Haryana. Photo: Kamal Narang.

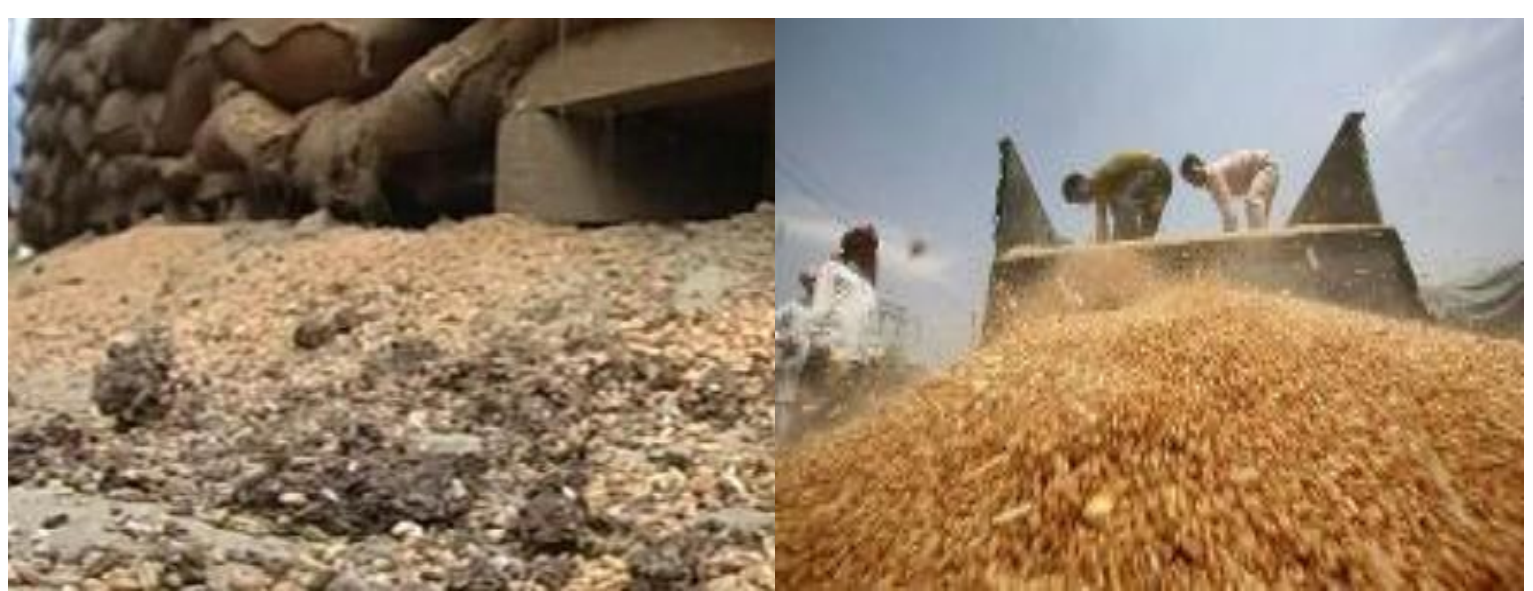

Picture--2

Picture--3

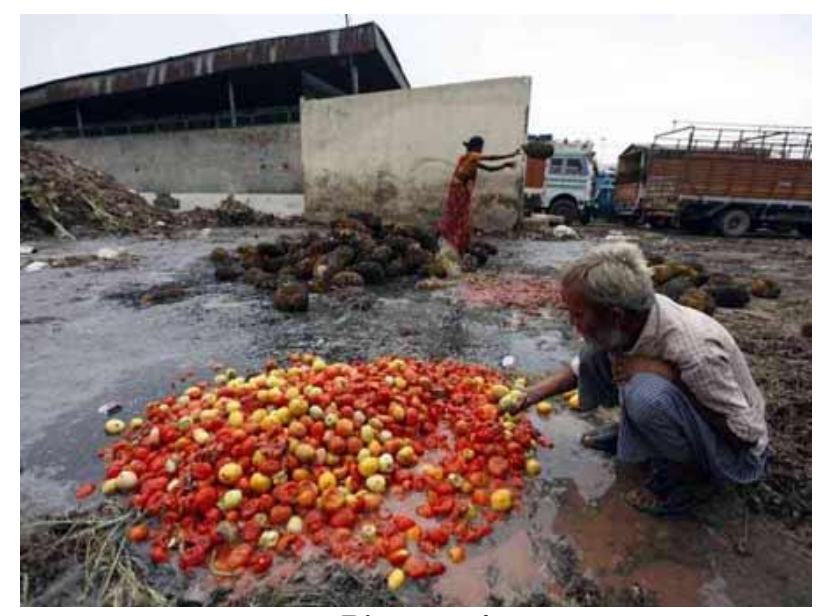

Picture--4

April 2013 saw farmers in West Bengal, India, venting their anger and

frustration by throwing The revelation exposes how government is struggling on two counts - safe storage of foodgrains and inadequate storage facilities for food items. Their year's yield of tomatoes on the roads. Having spent nearly 8 rupees $(\$ 0.15)$ for producing one $\mathrm{kg}$ of tomato and failing to get even 1 rupee (\$0.02) in the market, most farmers resort to selling their produce at a loss. Ironically, while farmers are incurring huge losses, end consumers are shelling out 12-15 rupees for a $\mathrm{kg}$ of tomatoes. (Story in Business Line)

Some glaring facts about Wastage of food in India:-

1. India, the world's second largest fruit and vegetable producer encounter a waste of close to $18 \%$ worth INR 44,000 crore ( $\$ 7$ billion) of produce.

2. The latest DIPP paper on Foreign Direct Investment (FDI) in retail estimated that against a production of 180 million metric tons a year of fruits, vegetables and perishables, India has a capacity of storing only 23.6 million metric tons in 5,386 cold storages across the country.

3. The Saumitra Chaudhuri Committee in 2012 indicated 61.3 million tonnes of cold storage requirement in the country against the present capacity of around 29 million tonnes.

4. The country lost INR 45 crore ( $\$ 7.2$ million) worth of food grain in the past 5 years (Data by Hindustan Times)

5. A report by the Institution of Mechanical Engineers reveal that each year, 21 million tonnes of wheat which is equivalent to Australia's annual grain production is wasted in India

6. Food Corporation of India (FCI) reports shows that food grain worth INR 120.29 crore (\$19.2 million) was lost in storage, while INR 106.18 crore (\$17 million) worth of grain was lost in transit. The remaining INR 
9.85 crore (\$1.5 million) worth of food grains were not fit for human consumption (Data from Business Line)

\section{Issues faced in India:----}

In spite of surplus food-grains stock, it is also a reality that a vast number of people do not have enough money to feed themselves twice a day.

1. Inadequate and improper storage facilities for grains, which are often stored outside under tarps that provide little protection from humidity and pests.

2 .Insufficient cold storage and cold chain transportation system is a major cause for fruits, vegetables and other perishable products to rot.

3. Poor roads and inefficient transport systems can cause massive delays. This in turn causes decay of temperature sensitive produce.

4. Limited reach of Mandis, which are currently the point of aggregation for agricultural produce. This poses problems for small farmers who don't have proper transport facilities at their disposal and have to travel and average of $12 \mathrm{~km}$ to the closest Mandi.

5 . Multiple layers of middlemen between the farmer and the end consumer, driving up prices and reducing bargaining power and price transparency for the farmers. These intermediaries have led to a cost inflation of $\sim 250 \%$ (over the cost of production).

6. Lack of a well-developed agricultural banking sector, which forces formers to take loans with high interest from commission agents.

7. Lack of education and training on new techniques, technologies and agricultural products.

8. There has been a gradual shift from cultivation of food crops to cultivation of fruits, vegetables, oil seeds, and crops which act also as industrial raw materials. This had led to the reduction in net sown area under cereals, millets and pulses.

9. The use of more and more land for construction of factories, ware-houses and shelters has reduced the land under cultivation and now fertile land for farming, is no longer available.

10. The productivity of land has started showing a declining trend. Fertilizers, pesticides and insecticides, which once showed dramatic results, are now being held responsible for reducing fertility of the soil

\section{Recommendations}

There is a need to shift from the existing expensive, inefficient and corruption ridden institutional arrangements to those that will ensure cheap delivery of requisite quality grains in a transparent manner and are self-targeting.

Futures market and free trade: The present system marked by input subsidies and high MSP should be phased out. To avoid wide fluctuations in prices and prevent distress selling by small farmers, futures market can be encouraged. Improved communication systems through the use of information technology may help farmers get a better deal for their produce. Crop insurance schemes can be promoted with government meeting a major part of the insurance premium to protect the farmers against natural calamities.

To start with, all restrictions on foodgrains regarding inter-State movement, stocking, exports and institutional credit and trade financing should be renounced. Free trade will help make-up the difference between production and consumption needs, reduce supply variability, increase efficiency in resource-use and permit production in regions more suited to it.

Food-for-education programme: To achieve cent per cent literacy, the food security need can be productively linked to increased enrolment in schools. With the phasing out of PDS, food coupons may be issued to poor people depending on their entitlement.

Modified food-for-work scheme/ direct subsidies: With rationalisation of input subsidies and MSP, the Central Government will be left with sufficient funds, which may be given as grants to each State depending on the number of poor.

The State government will in turn distribute the grants to the village bodies, which can decide on the list of essential infrastructure work the village needs and allow every needy villager to contribute through his labour and get paid in food coupons and cash.

Community grain storage banks: The FCI can be gradually dismantled and procurement decentralised through the creation of foodgrain banks in each block/ village of the district, from which people may get subsidised foodgrains against food coupons. The food coupons can be numbered serially to avoid frauds. The grain storage facilities can be created within two years under the existing rural development schemes and the initial lot of grains can come from the existing FCI stocks. If culturally acceptable, the possibility of relatively cheap coarse grains, like bajara and ragi and nutritional grains like millets and pulses meeting the nutritional needs of the people can also be explored. This will not only enlarge the food basket but also prevent such locally adapted grains from becoming extinct. The community can be authorised to manage the food banks. This 
decentralised management will improve the delivery of entitlements, reduce handling and transport costs and eliminate corruption, thereby bringing down the issue price substantially. To enforce efficiency in grain banks operation, people can also be given an option to obtain foodgrains against food coupons from the open market, if the rates in the grain banks are higher, quality is poor or services are deficient. A fund can be set up to reimburse the food retailers for the presented coupons. This competition will lead to constant improvement and lower prices. It must also be mandatory to maintain a small buffer stock at the State level, to deal with exigencies.

Enhancing agriculture productivity: The government, through investments in vital agriculture infrastructure, credit linkages and encouraging the use of latest techniques, motivate each district/ block to achieve local self-sufficiency in foodgrain production. However, instead of concentrating only on rice or wheat, the food crop with a potential in the area must be encouraged. Creation of necessary infrastructure like irrigation facilities will also simulate private investments in agriculture.

The focus on accelerated foodgrains production on a sustainable basis and free trade in grains would help create massive employment and reduce the incidence of poverty in rural areas. This will lead to faster economic growth and give purchasing power to the people.

A five-year transitory period may be allowed while implementing these. Thus, India can achieve food security in the real sense and in a realistic timeframe.

\section{Conclusion}

Global Hunger Index of 2013, India ranked 63rd out of 120 countries and this report is quite disturbing because India is one of the largest producers of food in the world. Overall, it may be concluded that food security in India can be achieved by paying higher attention to issues such as climate change, integrated water management, agricultural pricing, inadequate storage capacity, unsuccessful delivery of public services, mismanagement of food products and crop insurance. Despite considerable effort being made to improve production, not much focus has been given to curb food supply chain losses. With over 1.2 billion people to feed, addressing the issue of food wastage is essential to India's efforts towards combating hunger and improving food security.

The impact of globalization in the form of SEZs and other factors has been both positive and negative in terms of agricultural prosperity and there is a strong need to regulate the policies related to globalization for reducing its negative effects on food security in India. . Limit global warming, including the promotion of climate- friendly agricultural production systems and land-use policies at a scale to help mitigate climate change. In nutshell, Despite ensuring ample availability of food, existence of food insecurity at the micro-level in the country has remained a formidable challenge for India.

\section{References}

[1]. IFPRI, and Concern Worldwide: 2013 Global Hunger Index - The challenge of hunger: Building Resilience to Achieve Food and Nutrition Security. Bonn, Washington D. C., Dublin. October 2013.

[2]. Ghosh, S. and Brahmanand, P. S., Water and food security,Kurukshetra, 2009, 57, 19-20.

[3]. FCI reports .

[4]. The Department of Public Distribution of India, Internet.

[5]. Food and Agricultural Organisation(FAO) reports.

[6]. Ramesh, Jairam, The Economic Times, SEZs will need to meet the

[7]. land acquisition bill norms, dated 10 July 2012. 